\title{
Marketing communications in the digital age
}

\author{
Zhazira Idrysheva ${ }^{1, *}$, Nataliya Tovma ${ }^{1}$, Kyz-Zhibek Abisheva ${ }^{1}$, Meiramkul Murzagulova ${ }^{1}$, \\ and Nazym Mergenbay ${ }^{l}$ \\ ${ }^{1}$ Al-Farabi Kazakh National University, 050040,71 Al-Farabi Ave, Almaty, Kazakhstan
}

\begin{abstract}
In this article, the author raises the issues of marketing communications in the digital age. The article also presents the differences between traditional marketing communications and digital marketing. The theoretical basis includes the analysis of digital marketing tools and marketing communications. The empirical part of the study is carried out using two methods of research qualitative and quantitative parts in the form of questionnaires and logical method. As a result, based on theoretical and empirical findings, the author will provide recommendations and suggestions. In conclusion, it is revealed that digital marketing is a new trend in global marketing, aggressively and quickly pushing traditional advertising into the background.
\end{abstract}

\section{Introduction}

Digital marketing is a type of marketing that is widely used to promote products or services through digital technology in order to attract and retain consumers. Digital marketing goes beyond Internet marketing, including channels that do not require the use of the Internet. It is used in radio, mobile technology, television, the Internet, social media and contextual advertising and in many other forms of digital media. With digital media, consumers can access information anytime and anywhere they want. To get an idea of the growth of the Internet over the past fifteen years, it is enough to say that according to the data, by 2016 the Internet was used by 3.5 billion people, while in 2000 this number was only 400 million, which represents a growth rate of $875 \%$. Along with the growth of Internet use, there has been an increase in digital marketing. The main difference between traditional and digital marketing is that digital marketing focuses on the customer, offering him a personalized message and response to his request. Many search engines can be used in two important ways. The first way is search engine optimization (SEO), which helps companies show unpaid search results. This is the process of optimizing online content so that the search engine shows it as the main search result for a particular keyword. Another way is search engine marketing (SEM), which allows marketers to buy inventory as a result of a search. When they are online, in addition to browsing, users can see various materials. In addition to this content, they can also view ads in multiple forms, such as text, image, or video ads. This type of advertising is called display advertising.

\footnotetext{
*Corresponding author: madiyarova.aynur@mail.ru
} 
The main purpose of this work is to identify the effectiveness of marketing communications in digital marketing. The objectives are as follows: to show the different elements of digital marketing; to focus on the basic comparison between traditional and digital marketing; the impact of different forms of digital marketing on the company's sales and other activities; to show the various benefits of digital marketing for the client.

Additional advertising opportunities on the Internet are social networks, because they allow you to connect to the customer by creating a company profile on one of the social networks where customers are present. In addition to the above forms of marketing, you can use email marketing, which involves sending information and suggestions to people who have agreed to receive this kind of email.

\section{Literature review}

As Kannan noted, the term "digital marketing" has evolved over time from a specific term describing the marketing of products and services using digital channels to a generic term describing the process of using digital technology to attract customers and shape consumer preferences, promote brands, retain customers and increase sales. [1]

Communication in a digital environment has specific characteristics that differ from Autonomous interactions. In the digital age, "communication is" a fundamental condition for individual existence and social coexistence. Communication on the Internet is always unexpected, the choice of channel depends on the relationship between the parties, and the relationship affects the choice of channel [2].

Royle shows that there is a dearth of research examining gaps in digital marketing skills in the communications industries. His research focuses on the use of SNS (social networking jobs) in the B2B (business-to-business) market. He points to the need for expertise in digital marketing skills across industries and the damage that can be done if that skill set is missing. He suggests focusing on adaptive capabilities, providing intelligent protection for the future, market experimentation and relationship improvement, capitalizing on the media experience is the way forward for effective use of digital marketing opportunities [3].

According to Ahmad, evolution in the business world has manipulated the functions of social media to become one of the vital tools for marketing strategy, especially in the area of brand health and brand development. In the past era, business practices only adopt traditional marketing and also use Web 1.0. Thus, it is difficult for business practitioners to measure the health of their brand through engagement and audience growth. By now, the advent of Web 2.0 is giving a big Bang to the business world, especially in marketing, and making it easier for companies to measure their brand health through social media platforms. For example, using Web 2.0, it creates two ways of communication between customers and business communities, thereby ensuring active interaction between them [4].

In his work, Jacobson examines people's attitudes to the use of publicly available data on social media. While data breaches do occur, typically marketers will not have direct access to user data that is privately shared with a selected group of friends or shared only by members of online groups - at least not without users ' consent. But the situation is different when it comes to user content that is publicly posted on social media, such as a public post on Twitter or a comment on a public Facebook page. [5]

Communication through mobile social networks has two types: one-from the company to the consumer, i.e. B2C communication, and the other-UGC (user content). The first method is the definitive case of viral marketing promotions. The second type of communication, i.e. user content, is also considered an excellent promotion technique if the company does something unusual. There is a possibility that such a simple message can be converted by users into viral marketing campaigns. In April 2010, McDonald's followed an 
advertising strategy whereby it expanded\$ 5 and $\$ 10$ gift certificates to 100 users who registered at a particular McDonald's restaurant randomly. This campaign became so popular with users that a $33 \%$ increase In McDonald's sign - up was observed by simply spending less than $\$ 1,000$. [6]

Leeflang believes that the growing digitalization leads to serious problems for marketing executives. They face growing complex and rapidly changing markets that are beyond their control. As a result, firms have become aware of these changes and understood how to deal with them. Thus, he identified 10 digital marketing tensions based on discussions with marketers and practitioners. They can be divided into three categories: business strategy and customer understanding; operations and execution of market entry and third, organization and opportunities [7].

As Dwivedi highlighted, the rapid emergence and widespread adoption of information and communication technologies (ICT) and digital media have a significant impact on how people communicate and meet their socio-economic, emotional and material needs. ICT and digital media, such as email, search engines, websites and social networking sites, are already widely used by individuals for a variety of activities, including searching for daily news and updates on important events; connecting with family and friends; reviewing products, services and locations; selling and buying goods; access to transportation, travel and personal financial services; and managing jobs. In addition, a radical increase in both temporal and geographic reach allows consumers to influence brands, products and services. These technologies are also used by businesses for a variety of purposes, including distributing and selling goods, retailing consumer services, managing customer relationships, and influencing consumer behavior. So with the proliferation of ICT such as big data, artificial intelligence, GPS, Bluetooth, Zigbee, RFID, QR code and other mobile and Internet connected technologies, marketers can fine-tune their messages to effectively target segments within a country or region. Accordingly, these technologies develop digital marketing activities such as display advertising, affiliate marketing, search engine marketing, email marketing, social media marketing, and mobile marketing. [8]

Key gives the following definition to advertising, advertising is not a personal communication that is paid for and identified by a specific sponsor. Advertising by definition requires a message to communicate and some media platform to deliver the message. Marketing messages are necessary for all advertising elements, so the process of creating advertising is the first important step in IMC [9].

Obviously, people are showing themselves more and more on digital and social media. This is done for many purposes, including their role as consumers, as they seek information about products, buy and consume them, and communicate with others about their experiences. Marketers have responded to this fundamental shift by expanding the use of digital marketing channels. In fact, by 2017, about a third of global advertising spending is projected to come from digital channels. Thus, in the future, consumer marketing will be mainly carried out in a digital environment, especially in social networks and mobile devices. Therefore, it is necessary to investigate and understand consumer behavior in the digital environment. This has been happening over the last decade, and more research has focused on the problems of digital consumer behavior. However, the literature is still in its infancy, and more research is certainly needed - especially given the ever-changing nature of digital and social media in which consumers are and interact with brands [10].

According to Tiago, one of the biggest changes in human interaction is the recent proliferation of online social media. The rapid growth of web platforms that facilitate social behavior on the Internet has significantly changed the nature of human activities, environments, and interactions. Real social relationships have been transferred to the virtual world, leading to the creation of online communities bringing together people from all over 
the world. This movement into the digital dimension allows people to share knowledge, entertain each other and foster dialogue between different cultures [11].

Petit has proven that digital interactive technologies, especially touch technologies, are useful when it comes to creating a "web atmosphere" (i.e. consciously designing a web environment to create positive effects). These technologies can also help inform consumers about other sensory properties of the product, which are currently simply not available in most online environments [12].

According to Müller, digital, social media and mobile marketing (DSMM) describe a constant major transformation in marketing. It combines several technological developments that influence market research and practice[13].In the context of B2B, the use of DSMM remains insufficient, mainly focused on aspects such as brand image, rather than embedded in the search and purchase of industrial information, but it has significant potential [14].

Digital technologies are changing the world in which brands interact with their consumers. [15] New technologies create new markets, which in turn create new consumers and new competitors and make changes. For example, the emergence of online markets connecting consumers and manufacturers has eliminated the need for manufacturers to include some retailers in their value chain, allowing brand manufacturers to directly bargain with their customers [16]. This direct access to consumers leads to previously unavailable valuable information that can lead to better service and products.

Just as the use of social media is changing the way people live, learn and communicate with each other, fundamental shifts are taking place. in business with the introduction and use of social networks [17]. Consumers use social media to get information and share experiences with their friends, businesses, and wider online communities through posts, tweets, posts, likes, and reviews. [18] Enterprises pay attention to the fact that they adopt strategies and tools to attract listeners in social networks [19]. Marketers have a particular interest in marketing, combining social media and Analytics to gather information about potential new products [20].

Traditional marketing is the most recognizable form of marketing. Traditional marketing is a non-digital way. It is used to promote products or services. Digital marketing, on the other hand, is the marketing of products or services using digital channels to reach consumers.

Some comparisons are presented below.

Advertising media that can be used as part of a digital marketing strategy of a business may include advertising activities carried out through the Internet, social networks, mobile phones, electronic billboards, and digital television and radio channels. Digital marketing is a sub-branch of traditional marketing and uses modern digital technologies.

There are various tools by which digital marketing is formed. All forms work through electronic devices. The most important elements of digital marketing are listed below:

1. online advertising. Online advertising is a very important part of digital marketing.Online advertising provides content and ads that best suit the interests of consumers. Publishers talk about their products or services on their websites so that consumers or users get free information. Advertisers should place more effective and relevant ads online. Thanks to online advertising, the company is well in control of its budget and has full control.

2. Email marketing. When a product or service message is emailed to an existing or potential consumer, it is defined as email marketing. Direct digital marketing is used to send advertising, to build brand and customer loyalty, to build customer trust and make brand awareness.A company can enhance its products and services with this element of digital marketing easily. This is a relatively low cost compared to advertising or other forms 
of media exposure. The company can capture the full attention of the customer by creating graphics, text and links to products and services .

3. Social network. Social media marketing provides firms the opportunity to use social networks to build relationships with customers, employees, communities, and other stakeholders (i.e., when they act as researchers). At the same time, firms can choose to view social media, another communication channel through which they can communicate information to customers(i.e. when they act as advocates). [21]Today, social media marketing is one of the most important channels of digital marketing. It is a computer tool that allows people to create, share ideas, information and photos about a company's product. Social networks are channels of information, the way we share our lives through pictures, words, videos. This is a kind of transfer of our attitude to other people, objects, programs, events, etc. This is what unites us and what shows how we share information with each other. Forms of social media transmission are divided into 10 categories: publishing tools, sharing tools, discussion tools, social networks, micro-publishing tools, social aggregation tools, live streaming, virtual worlds, social games and multiplayer online games [22].

Social media marketing networks include Facebook, Twitter, LinkedIn and Google+. Through Facebook, the company can promote events related to products and services, conduct promotions. Through Twitter, a company can increase awareness and visibility of their brand. It is the best tool to promote the company's products. Microblogging sites such as Twitter can also be useful to managers in sharing important news and timely information that may be relevant to the firm's clients [23].

On LinkedIn, professionals write their profile and share information with others. The company can design your LinkedIn profile so that professionals can view and receive more information about the company and their products. Google+ is also a social network that is more efficient than other social networks like Facebook, Twitter. It is not only a simple social network, but also an authorship tool that links web content directly to its owner.

4. Text messaging. It is a way of sending information about products and services from mobile and smart phone devices. Using telephone devices, the company can send information in the form of text (SMS), photos, video or audio (MMS). Marketing via mobile phone SMS (short message service) was more popular in the early 2000s in Europe and parts of Asia.

Using SMS for campaigns, you get faster and more substantial results. Under this method, a company can send marketing messages to its customers in real time, at any time and can be sure that the message will be seen. The company can create a profile and get valuable customer feedback and develop its products or services in the future.

5. Affiliate marketing: Affiliate marketing is a type of performance-based marketing. The industry has four major players: the merchant (also known as the" retailer "or" brand"), the network, the publisher (also known as the" partner"), and the customer.The market has grown in such complexity, resulting in secondary-level players, including partner management agencies, affiliates, and specialized vendors.

There are two ways to approach affiliate marketing: a company can offer an affiliate program to others or it can sign up to be a partner of another business. If the company wants to manage the affiliate program, the owner of the company must pay a Commission to the partners for every sale and visit to the company's website. The main goal of the company here is to find partners who can enter unused markets.

6. Search engine optimization (SEO) is a process that affects the visibility of a website or webpage on the Internet.In General, the earlier (or higher in rank the search results page), and the more often a site appears in the search results list, the more visitors it will receive from search engine users. SEO can target various types of search, including image 
search, local search, video search, academic search, news search, and industry vertical search engines.

7. Pay per click (PPC). Pay-per-click marketing is a way of using search engine advertising to generate clicks on your website.Pay per click is good for search engines and advertisers. This is the best way to advertise a company as it brings low cost and great engagement with products and services.

Table 1. Comparison of traditional marketing and digital marketing.

\begin{tabular}{|l|l|}
\hline Traditional marketing & Digital marketing \\
\hline $\begin{array}{l}\text { Traditional marketing includes print, television, } \\
\text { mail and telephone }\end{array}$ & $\begin{array}{l}\text { Digital marketing includes Internet advertising, } \\
\text { electronic marketing, and } \\
\text { marketing, social media, text messaging, } \\
\text { partner } \\
\text { marketing, search engine optimization }\end{array}$ \\
\hline No interaction with the audience. & Interaction with the audience \\
\hline The results are easy to measure. & The results are pretty much easy to measure \\
\hline $\begin{array}{l}\text { Advertising campaigns are planned for a long } \\
\text { time. }\end{array}$ & $\begin{array}{l}\text { Advertising campaigns are planned in a short } \\
\text { time }\end{array}$ \\
\hline Expensive and time-consuming process. & $\begin{array}{l}\text { A fairly cheap and fast way to promote } \\
\text { products or services }\end{array}$ \\
\hline $\begin{array}{l}\text { Success of traditional marketing strategies-if } \\
\text { the firm can reach a large local audience. }\end{array}$ & $\begin{array}{l}\text { The success of a digital marketing strategy is } \\
\text { considered if a firm can reach a specific number } \\
\text { of local audiences }\end{array}$ \\
\hline One campaign for a long time. & $\begin{array}{l}\text { Campaigns can be changed with ease and } \\
\text { innovations can be implemented within any } \\
\text { campaign }\end{array}$ \\
\hline $\begin{array}{l}\text { Limited client access due to limited number of } \\
\text { client technologies. }\end{array}$ & $\begin{array}{l}\text { Wider reach to the client due to the use of } \\
\text { various technologies }\end{array}$ \\
\hline $\begin{array}{l}\text { Round-the-clock year-round exposition is } \\
\text { impossible. }\end{array}$ & $\begin{array}{l}\text { Round-the-clock year-round exposition is } \\
\text { possible }\end{array}$ \\
\hline There is no way to go viral. & Opportunity to go viral \\
\hline One way to talk. & Two ways to talk. \\
\hline $\begin{array}{l}\text { Responses can only occur during business } \\
\text { hours. }\end{array}$ & Response or feedback can occur at any time \\
\hline
\end{tabular}

Consider the main differences between Internet marketing and digital marketing:

Table 2. Differences between Internet marketing and digital marketing

\begin{tabular}{|l|l|l|}
\hline Indicators & Internet marketing & Digital marketing \\
\hline $\begin{array}{l}\text { The scope of impact on the } \\
\text { target audience. }\end{array}$ & Online sphere. & Online + offline \\
\hline Distribution channel. & The Internet channels. & $\begin{array}{l}\text { All kinds of digital channels } \\
\text { (Internet, mobile applications, } \\
\text { digital advertising, tablets and } \\
\text { game consoles, digital TV, } \\
\text { etc.) }\end{array}$ \\
\hline Target audience. & $\begin{array}{l}\text { Everyone who has access to } \\
\text { the Internet. }\end{array}$ & $\begin{array}{l}\text { Everyone who has access to } \\
\text { the Internet + attracting offline } \\
\text { audience to the online market }\end{array}$ \\
\hline $\begin{array}{l}\text { A way to communicate with } \\
\text { the audience. }\end{array}$ & $\begin{array}{l}\text { E-mail newsletters, landing } \\
\text { pages, websites, advertising } \\
\text { (search, banner, targeted, } \\
\text { contextual), etc. }\end{array}$ & $\begin{array}{l}\text { Digital television, advertising } \\
\text { in online games and mobile } \\
\text { applications, messengers, } \\
\text { interactive screens, POS- } \\
\text { terminals, local networks of } \\
\text { large cities. }\end{array}$ \\
\hline
\end{tabular}




\section{Methodology}

The methodology is based on systematic and theoretical analysis. This study is based on both primary and secondary data.

A primary source is the source from which we collect first-hand information, or raw data on a topic. Interviews a structured questionnaire technique was used to collect primary data.

A secondary source is a source from which we collect data that has already been collected by someone. We have collected secondary data from published financial reports of firms, Newspapers and articles.

For the purposes of this study, we selected one hundred and fifty firms randomly that use digital marketing technologies. In addition, we also collected data from 50 executives from a sample of other different firms to get their opinions on the effectiveness of digital marketing.

The data and information collected were organized, explained and analyzed using various statistical tools and techniques. This study shows the results in both descriptive and analytical form.To show the relationship between different elements of digital marketing and increased sales, we have collected data from one hundred and fifty firms that adopt different methods or elements of digital marketing.

The results are given below.

Table 3. Correlation between digital marketing elements.

\begin{tabular}{|l|l|l|l|l|l|l|l|l|l|}
\hline & & $\begin{array}{l}\text { Increas } \\
\text { e in } \\
\text { sales. }\end{array}$ & $\begin{array}{l}\text { Onlin } \\
\text { e } \\
\text { adver } \\
\text { tising }\end{array}$ & $\begin{array}{l}\text { E- } \\
\text { marketi } \\
\text { ng }\end{array}$ & $\begin{array}{l}\text { Mass } \\
\text { media }\end{array}$ & $\begin{array}{l}\text { Inform } \\
\text { ation }\end{array}$ & $\begin{array}{l}\text { Affiliat } \\
\text { e } \\
\text { market } \\
\text { ing }\end{array}$ & $\begin{array}{l}\text { SearchE } \\
\text { ngineOp } \\
\text { timizati } \\
\text { on } \\
\text { (SEO) }\end{array}$ & $\begin{array}{l}\text { PayP } \\
\text { erCli } \\
\text { ck } \\
\text { (PPC } \\
\text { ) }\end{array}$ \\
\hline $\begin{array}{l}\text { Incre } \\
\text { ase. } \\
\text { Sales' }\end{array}$ & $\begin{array}{l}\text { Correl } \\
\text { ation } \\
\text { (r) }\end{array}$ & 1 & .869 & .873 & .840 & .667 & .560 & .840 & .560 \\
\cline { 2 - 9 } & $\begin{array}{l}\text { Sig. } \\
\mathrm{N}\end{array}$ & 150 & $\begin{array}{l}.056 \\
150\end{array}$ & $\begin{array}{l}.053 \\
150\end{array}$ & $\begin{array}{l}.075 \\
150\end{array}$ & $\begin{array}{l}.219 \\
150\end{array}$ & $\begin{array}{l}.326 \\
150\end{array}$ & $\begin{array}{l}.075 \\
150\end{array}$ & $\begin{array}{l}.326 \\
150\end{array}$ \\
\hline
\end{tabular}

From the table below, we can conclude that each element of digital marketing is positively associated with increased sales. This suggests that all elements of digital marketing have a positive impact on the company's sales. Online advertising, email marketing, social media and search engine optimization (SEO) correlates very positively with increased sales, as it shows a value of $\mathrm{r} .869, .873, .840$ and .840 , respectively. The $\mathrm{R}$ value of text messaging, affiliate marketing and pay-per-click (PPC) are .667, .560 and .560 which show a low positive correlation with sales growth.

According to the results of the survey the following types of digital marketing have the greatest impact on the number of attracted consumers:

Table 4. Effects of digital marketing communications on B2B and B2C.

\begin{tabular}{|l|c|c|}
\hline Types of digital marketing & B2B & B2C \\
\hline Social media marketing & $17,9 \%$ & $24,8 \%$ \\
\hline Search engine optimization & $57,4 \%$ & $41,0 \%$ \\
\hline Contextual advertising & $24,8 \%$ & $34,2 \%$ \\
\hline
\end{tabular}

For B2B marketers, search engine optimization (SEO-57.4\%), contextual advertising $(24.8 \%)$ are the most important. Marketing campaigns on social networks were considered important by only $17.9 \%$ of respondents. 
For B2C marketers, the importance of SEO is slightly less important (41\%), but contextual advertising (34.2\%) and social media marketing (24.8\%) are more significant.

\section{Results and discussion}

When answering some questions of the electronic questionnaire, respondents had the opportunity to choose several options for the answer. In the block of questions about the most and least popular digital services, participants were asked to choose the most and least popular services.

The least popular digital services, according to experts, were the following: development of solutions for the Internet of things (64\%), customerDevelopment and UX (userexperience) design (60\%), highload-development of complex digital projects $(56 \%)$, services for the development of augmented (AR) and virtual reality (56\%), marketing and analytical research (40\%), consulting services (40\%), performance-marketing (CPA marketing) (36\%), web Analytics (36\%), development of chatbots (32\%), reputation marketing in the digital environment $(28 \%)$.

The questionnaire also contained questions about the method of evaluating the effectiveness of digital communications by specialists and their clients. The specialists themselves evaluate the results of their work with such indicators as the cost of the attracted client $(80 \%)$, lead $(68 \%)$ and conversions $(64 \%)$. When as for their customers are more important followings: the cost of clicks, leads and conversions (72\%).

The results of the survey showed that the following services are most in demand in the Kazakh market: SMM (88\%), targeted advertising (84\%), contextual advertising (80\%), website development (76\%), SEO-optimization (64\%), digital design and creativity $(56 \%)$, integrated digital services $(56 \%)$, video production for digital projects $(56 \%)$, mobile application development (36\%), CRM system integration (36\%), content marketing in the digital environment (36\%), as well as motion-design and animation for digital-projects $(32 \%)$.

The results of the survey showed that in 2019-2020, the situation in the market in Kazakhstan's digital services industry will improve, and the market volume will increase. Agencies still offer "technically" not very complex services, but the competence of the market is growing, and in the future digital agencies will offer the market even more complex from a technical point of view solutions.

Offers:

1. improvement of technical progress in digital marketing promotion.

2. collect and implement the feedback provided by the consumer in the right way.

3. make transparent and good service to the consumer before and after the purchase.

4. creating awareness among people about digital marketing.

5. provide full description about the product for online buyers.

Digital e-development strategies should consider the following issues:

1. Access and use;

2. Favorable conditions;

3. Human potential;

4. Global and National Governance Issues;

\section{Conclusion}

This article presents digital advertising technologies, methods and media and their advantages and disadvantages. Understanding how search engines work and advertising on them are the most important elements for the promotion of a quality product. Social 
networks are one of the most famous tools. They enable day-to-day interaction with customers and help build brand awareness. The biggest advantage of social media advertising is the different customer details they have, making it easy to find the perfect customers. E-marketing allows us to complement all forms of digital marketing mentioned above, primarily through the acquisition of e-mail addresses of already interested users.In addition, unlike traditional marketing, digital marketing is measurable. You can see which ad was most interesting to the audience and the one that did not like, and then adjust the advertising strategy accordingly. Knowing your costs and calculating the amount invested and received is important for every business person, and digital marketing makes it possible.

Digital marketing has no boundaries. The company can use any devices such as smartphones, tablets, laptops, TVs, game consoles, digital billboards, as well as media such as social networks, SEO (search engine optimization), video, content, email and more to promote the company itself and its products and services.

Digital marketing can succeed more if it considers the needs of users as a top priority. Companies should create innovative customer experiences and specific strategies for the media to identify the best way to increase the effectiveness of digital marketing.

The authors thank all anonymous reviewers for their helpful remarks. This research was supported by the AP05135078 "Formation and development of the digital economy in the Republic of Kazakhstan: theory and practical measures of implementation" scientific project.

\section{References}

1. P. K. Kannan, Int. J. Res. Market. 34(1), 22-45. (2017).

2. M., Shumate, A. O'Connor, J. Communic. 60(3), 577-609. (2010).

3. J. Royle, A. Laing, Int. J. Inform. Manag. 34(2), 65-73. (2014).

4. N. S. Ahmad, R. Musa, M. H. M. Harun, Proc. Econ. Fin. 37, 331-336. (2016).

5. J. Jacobson, A. Gruzd, Á. Hernández-García, J. Retail. Cons. Serv. (2019)

6. M. Yadav, Y. Joshi, Z. Rahman, Proc.-soc. Behave. Sci. 189, 335-343. (2015).

7. P. S. Leeflang, P. C. Verhoef, P. Dahlström, T. Freundt, Europ. Manag. J., 32, 1-12 (2014)

8. Y. K. Dwivedi, N. P. Rana, E. L. Slade, N. Singh, H. Kizgin, Editorial introduction: Advances in theory and practice of digital marketing (2019)

9. T. M. Key, A. J. Czaplewski, Bus. Horiz. 60(3), 325-333. (2017).

10. A. T. Stephen, Cur. Opin. Psych. 10, 17-21. (2016).

11. M. T. P. M. B. Tiago, J. M. C. Veríssimo, Bus. Horiz. 57(6), 703-708. (2014).

12. O. Petit, C. Velasco, C. Spence, J. Inter. Market. 45, 42-61. (2019).

13. J. M. Müller, B. Pommeranz, J. Weisser, K. I. Voigt, Ind. Market. Manag. 73, 7083. (2018).

14. J. Järvinen, A. Tollinen, H. Karjaluoto, C. Jayawardhena, Market. Manag. J. 22 (2012).

15. K Gielens, J. B. E. Steenkamp, Int. J. Res. Market. (2019).

16. B. E. Kahn, J. J. Inman, P. C. Verhoef, J. Associat. Cons. Res. 3, 255-259. (2018).

17. A. Quan-Haase, A. L. Young, Bull. Sci. Tech. Soc. 30(5), 350-361 (2010)

18. A. A. Bailey, C. M Bonifield, A. Arias, J. Ret. Cons. Serv. 43, 10-19 (2018)

19. N. Misirlis, M. Vlachopoulou, Int. J. Inform. Manag., 38(1), 270-276 (2018)

20. R. Dimitriu, R. Guesalaga, Psych. Mark. 34(5), 580-592 (2017)

21. R. Felix, P. A. Rauschnabel, C. Hinsch, J. Bus. Res. 70, 118-126 (2017)

22. S. Ziyadin, A. Serikbek, Springer, Cham. 290-297 (2019)

23. G. Killian, K. McManus, Bus. Horiz. 58(5), 539-549. (2015) 